\title{
Increasing English Vocabulary Mastery Through Teams Games Tournament Using Word Square of Seventh Grade Students in SMP Frater Don Bosco Tomohon
}

\author{
Perzeus D. M. Mangindaan ${ }^{1}$, I Nengah Sudipa², I Nyoman Suparwa ${ }^{3 *}$ \\ ryovalion@gmail.com \\ Universitas Udayana, Denpasar 80114, Indonesia
}

\begin{abstract}
This research is aimed to describe and analyze the students' mastery in English vocabulary before and after applying the teams games tournament using word square. Also, to analyze the influencing factors that increase students' vocabulary mastery. The samples of this research are 22 students of class 7 from SMP Frater Don Bosco Tomohon. The research is an experimental study with a descriptive quantitative and qualitative approach used quasi-experimental, pretest and posttest one-group design. The methods used in collecting the data are interview, observation, questionnaire, and test. To analyze the data, quantitative and qualitative methods are used accordingly. The theories used in this research are teams games tournament theory, constructivism theory, and vocabulary learning theory. The result of this research showed that after applying teams games tournament using word square, the students' mastery in English vocabulary are increased. There are 20 students have fulfilled the standard completeness score while only 2 students who have not. The class average score reached 82.81 (good). Based on the paired sample t-test conducted, it is known that the $t_{\text {count }}$ value is greater than the $t_{\text {table }}$ which is $9.388>2.079$. Thus, it can be concluded that there is an effect of applying the teams games tournament using word square towards English vocabulary learning.
\end{abstract}

Published by IJRP.ORG. Selection and/or peer-review under responsibility of International Journal of Research Publications (IJRP.ORG)

Keywords: learning method; teams games tournament; word square; vocabulary

\section{Introduction}

English is considered as the most important and influential language compared to the other foreign languages. It is utilized by majority of people around the world in order to communicate. The language becomes more important for people who are in a professional and educational environment because most of the essential information are presented on English, this includes books, movies, music, and online content. Furthermore, in formal education English is the only foreign language within the list of subjects in the Indonesians' National Examination from junior to senior level. In Indonesia, English is used as a foreign language which makes it difficult to master. Thompson, 2012 stated that someone who uses or learns a second 
language will take as much as seven years to reach the same level of proficiency expected from the native speaker learners.

Vocabulary becomes an essential aspect in language learning especially in English. It is a basic knowledge in order to learn the four language skills which are reading, writing, listening, and speaking. Cameron, 2001 stated that vocabulary is a central to English language learning that play a great role for learners in acquiring the language. Similar to Cameron's opinion, Tarigan, 1993 also stated that a person's language skill depends on the quantity and quality of vocabulary he or she has. The richer one's vocabulary, the better one's language skill is. On the other hand, Rivers, 1972 said that it is impossible to learn a language without learns its vocabulary. Learning a language is learning its vocabulary.

Teaching vocabulary is not an easy task. It takes more than simply look inside a dictionary to find a meaning to achieve a proper sentence. Students are not only expected to know vocabulary but they must fully understand the meaning and when to use them. In other words, vocabulary mastery is not a matter of knowing every single word but the ability to understand and to actively use them in a proper way. Factors of students' poor English vocabulary are: (1) students' insufficient knowledge; (2) students' lack of interest towards English text; (3) dull instruments in teaching vocabulary; (4) low qualities of tasks and exercise given; and (5) a less proper teaching method applied. This problem occurred in class 7A, SMP Frater Don Bosco.

The primary issue experienced by the students is their lack of knowledge regarding the English basics due to removal of English subject from elementary school's curriculum. On top of that is the teacher way of introducing new words where memorizing and literary translating is considered enough without explaining the contextual meaning. Students are not motivated to learn English due to low level of understanding towards the presented vocabulary. Aside of these, the instrument used are limited to the exercise book from school. It appears that teacher has not yet implemented the proper method and the right instrument to increase students' vocabulary mastery.

In line with this issue, a particular method and instrument is implemented to be able to attract and motivate students in learning English especially vocabulary. A cooperative learning method which focusing in the principal of working in groups is considered as a proper method. Therefore, teams games tournament using word square has been proved in response to the problem arisen. So far there are limited studies encountered combining this method and instrument, and in fact there seem to be zero finding of both being designated for English vocabulary learning.

\section{Theoretical Framework}

\subsection{Teams games tournament theory}

Team games tournament (TGT) is one of the cooperative learning methods developed by Davis de Vries and Keith Edwards. This is the first learning method applied in John Hopkins. This method is a combine learning technique of group discussion and games. A research of Berlmutter and de Montmollin shows that students in groups are learning faster and more effective as they are cooperating together to complete their own tasks. In groups study, there are insights of relation, interaction, participation, contribution, affection, and dynamic. Cooperation in a group has a lot to contribute in education and learning. Slavin, 1995 stated that there are five steps to be applied in the process of teams games tournament learning method which are as follows:

\subsubsection{Class presentation}

This step is also known as warming up session where the teacher delivers the main idea of the subject through short briefing as well as question and answer. The difference between class presentation and normal 
briefing is that in class presentation, one has to focus on the teams games tournament unit. During the class presentation, the students are expected to pay attention and understand the subject delivered by the teacher. This is a basic knowledge prior to their contribution in a group study as well as during the academic tournament in order to determine their group's score.

\subsubsection{Team formation}

In this session, the students are divided into heterogeny groups. Each groups are being given tasks to study with a goal where all members will easily understand the subject in order to optimally participated in the next step.

\subsubsection{Game}

The teacher presented a few questions through a game to evaluate their knowledge achieved from the previous steps. The game consists of several simple questions, it could be an oral or written. There will be a score given for every correct answer and the score will be accumulated for the tournament purposes.

\subsubsection{Tournament}

Tournament are conducted at the end of one topic of learning subject given. In this session, the students will participate in an academic tournament where each of the team will compete to be the winner. Prior to the tournament, new homogeny teams will be formed which delegated from their group study. This will allow them to fairly compete with each other of the same academic level. The students' academic level is determined from their score of the game session. In this tournament, students' individual accountability is taken care of so they will not be able to help the other member in their group during competition.

\subsection{Constructivism theory}

It is the development basic of cooperative learning, peer interaction learning, group learning, and problem posing learning. This theory stated that students have to independently find and transform a complex information, check new information bearing in mind old rules and patters, and revised them if the rules are no longer essential. The primary objective of constructivist learning is how students able to build their own knowledge through their proactivity in the learning process. Vygostky stated that it is a tiered based knowledge known as scaffolding. Scaffolding is a way where basic knowledge and assistances are given at the beginning of the learning process and then in time, deducting the help given. The next step is to give students bigger responsibility once they are able to do it themselves. The assistances given may be in a form of clues, encouragement, and how to reconstruct problem into a different form which allows the students to be independent. This theory is applied as the basic in applying teams games tournament using word square and in analyzing the influencing factors that affect the increasing of students' English vocabulary mastery.

\subsection{Vocabulary learning theory}

Vocabulary is not something that can be completely mastered as it will keep growing new ones over the time. Nation, 2001 mentioned that students must enrich their vocabulary because it is not something that can be done instantly. Vocabulary are continuously learned whether it is coincidentally presented through a sentence or explicitly explained as a word in a particular vocabulary learning subject. Harmer, 2001 stated that in teaching vocabulary, one must know how to choose the right series of words for a specific level of students. The main principal in choosing the vocabulary is to consider how often they are being used (factor frequency). He also added that in order to gain control over vocabulary, a student has to have a sufficient 
knowledge about their meaning, how they are used, their formation and how they appear like in a proper grammar. Based on Harmer theory there are four important aspect in learning vocabulary which are meaning, function, spelling, and pronunciation. This is the theory used in analyzing the students' vocabulary mastery.

\section{Method}

This is an experimental research with descriptive quantitative and qualitative approach. The descriptive quantitative approach is used to analyze the increasing of students' English vocabulary mastery through pretest and posttest, and to figure out the effect learning method given. Meanwhile, the descriptive qualitative. Approach is used to describe the students' English vocabulary mastery before and after the teams games tournament using word square applied. A quasi-experimental, pretest and posttest one-group design used where the research conducted without a group comparison. Pretest and posttest scores are designated to measure the effectiveness of the research.

\section{Result and Discussion}

\subsection{Students' English vocabulary mastery before applying the teams games tournament using word square}

Before applying the teams games tournament using word square, a pretest is being conducted to obtain an initial data of the students' English vocabulary mastery. The pretest consists of word form, synonym, antonym, and word use in simple present sentence. The pretest result is shown as follow.

Table 1. Students' pretest scores

\begin{tabular}{ll}
\hline Total score & 1108 \\
Mean score & 50.36 \\
Highest score & 70 \\
Lowest score & 36 \\
$\begin{array}{l}\text { Percentage of minimum standard competence } \\
\text { achieved }\end{array}$ & $0 \%$ \\
\hline
\end{tabular}

Based on the data above, it is shown that all students have not yet reached the standard completeness score given by the school $(\geq 75)$. Meanwhile, the mean score achieved is 50.36 which can be categorized as 'poor'. In other words, the students have a low English vocabulary mastery before the teams games tournament using word square applied.

\subsection{Students' English vocabulary mastery after applying the teams games tournament using word square}

The posttest is conducted after the three sessions treatment to obtain a final data of the students' English vocabulary mastery. In practice, the form of posttest is the same as pretest to obtain an accurate and significant comparison between both scores. The scores comparison between pretest and posttest are shown as follow. 
Table 2. Score comparison of pretest and posttest

\begin{tabular}{lll}
\hline & Pretest & Posttest \\
\hline Total score & 1108 & 1822 \\
Mean score & 50.36 & 82.81 \\
Highest score & 70 & 98 \\
Lowest score & 36 & 74 \\
$\begin{array}{l}\text { Percentage of minimum standard competence } \\
\text { achieved }\end{array}$ & $0 \%$ & $90.90 \%$ \\
\hline
\end{tabular}

The data shown a significant increase compared to the pretest result. There are 20 students have fulfilled the standard completeness score while only 2 students left who have not. The mean score achieved is 82.81 which can be categorized as 'good'. After knowing both test results and comparison, continued with hypothesis test through paired sample t-test. Based on the paired sample t-test conducted, it is known that the $t_{\text {count }}$ value is greater than the $t_{\text {table }}$ value, it is $9.388>2.079$. Thus, it can be concluded that the teams games tournament using word square is successfully contribute to increase students' English vocabulary mastery.

\subsection{The influencing factors in increasing students' English vocabulary mastery}

It is known that the teams games tournament using word square helps students to increase their English vocabulary mastery. However, based on the result of observation and questionnaire there are other factors that also affect the increase. Those factors can be classified as internal factor and external factor as described below.

\subsubsection{Internal factor}

The internal factor comes from oneself or from a learning individual. In other words, this factor related to the motivation that comes from each individual in order to do or achieve something. The internal factor is classified into two, which are physiological factor and psychological factor. The psychological factor includes students' motivation, interest, and comprehension.

\subsubsection{External factor}

The external factor originates come from anything around the students that affects the learning process. It includes elements from the students' environment, which are classroom environment, learning method, and instrument.

\section{Conclusion}

1. The pretest before applying the teams games tournament using word square in English vocabulary learning shown that all students have not yet reached the standard completeness score given by the school. The mean score achieved is only 50.36 which categorized as 'poor'.

2. Teams games tournament using word square is applied in class $7 \mathrm{~A}$ as a treatment. The treatment conducted in three sessions for 80 minutes for each session. The posttest shown that the students' English vocabulary mastery is increased. There are 20 students have fulfilled the standard completeness score given, while only 2 students left who have not. The mean score achieved is 82.81 which categorized as 'good'. 
3. There are other factors that affect the increasing of students' English vocabulary mastery namely internal factor and external factor. The internal factor are physiological and psychological factor, meanwhile the external factor includes classroom environment, learning method, and instrument.

\section{References}

Arikunto, S., 2006. Metode Penelitian Kualitatif, Editor. Bumi Aksara, Jakarta.

Cameron, L., 2001. Teaching Language to Young Learners, Editor. Cambridge Universiry Press, Cambridge, p.1-6.

Harmer, J., 2001. The Practice of English Language Teaching, Editor. Longman, London, p.16.

Rivers, W. M., 1972. Teaching Foreign Language Skills, Editor. Chicago Universiry Press, Chicago.

Slavin, 1995. Model Pembelajaran Kooperatif, Editor. Balai Pustaka, Jakarta.

Tarigan, H. G., 1993. Strategi Pengajaran dan Pembelajaran Bahasa, Editor. Angkasa, Bandung, p.109.

Vygotsky, L., 1978. Mind in Society: The Development of Higher Psychological Process, Editor. Harvard University Press, Cambridge. 